\title{
Cost benefit study with Vi vaccine
}

V. Nguyen, S. Lescure

\begin{abstract}
Abstrak
Demam tifoid merupakan infeksi umum dari sistem retikuloendotelial, jaringan limfoid usus, dan kantung empedu yang disebabkan oleh Salmonella typhi. Insidens penyakit ini pada populasi di Indonesia diperkirakan berkisar antara 0,5\% - 1\%. Walaupun tersedia sejumlah antibiotik untuk mengobati penyakit ini, adanya resistensi ganda menyebabkan lambatnya pengobatan yang efektif dan meningkatkan komplikasi, angka kematian dan biaya pengobatan. Vaksin demam tifoid relatif jarang digunakan. Walaupun demikian, taksiran ekonomi dari konsekuensi yang timbul jika vaksin ini dipakai untuk pencegahan demam tifoid mungkin bermanfaat. Dengan adanya data ini akan membantu para pengambil keputusan untuk melengkapi data klinis dasar. Tujuan penelitian ini ialah untuk mengevaluasi, secara ekonomi, vaksin demam tifoid dibandingkan dengan pengobatan standar demam tifoid di 4 daerah pertambangan yang terpisah secara geografis. Populasi termasuk pekerja dan keluarganya. Dengan menggunakan catatan administrasi dari pelayanan perawatan kesehatan dari Indonesia, kami mengadakan simulasi dampak ekonomi dari vaksin: biaya langsung yang dihubungkan dengan pengelolaan/pengobatan penyakit dan biaya tak langsung yang dibutuhkan dihubungkan dengan hilangnya hari kerja (absen). Hasil menunjukkan bahwa pengobatan standar menelan biaya sebesar Rp. 5.498.776,- untuk mengobati 22 pasien, atau Rp. 249.944,--pasien. Sementara itu, program vaksinasi memakan biaya Rp. 2.127.740 untuk memvaksinasi 260 orang dimana risiko pertahun untuk,terkena penyakit sebesar $23 \%$ dan insidens penyakit ini ialah 0,0846. Keuntungan bersih dari perusahaan sebesar Rp. 3.371.036,-. Rasio dari keuntungan secara ekonomis ialah 1:58; secara singkat perusahaan menghemat $R p$. 1,58,- untuk setiap Rp. 1,00 yang dihabiskan untuk program. Penelitian ini memperlihatkan bahwa vaksin demam tifoid dapat menghemat biaya pada pengelolaan pasien demam tifoid pada lingkungan pekerjaan. Hal ini menunjukkan bahwa pencegahan demam tifoid menggunakan vaksin tifoid dapat menghemat biaya di lingkungan lainnya.
\end{abstract}

\begin{abstract}
Typhoid fever is an acute generalized infection of the reticuloendothelial system, intestinal lymphoid tissue, and gall bladder caused by Salmonella typhi. The incidence of the disease is estimated in Indonesia at between 0.5 to $1 \%$ of the population. Although there are a number of antibiotics available to treat the disorder, the multi-resistant effects of antibiotics can delay effective treatment and increase the number of complications, mortality rate and the treatment cost. Typhoid fever vaccine is underused. However, an ex-ante economic appraisal of the expected consequences of its introduction in the prevention of typhoid fever may be valuable. This would provide decision makers with information to complete standard clinical data. The aim of this study is to evaluate, in economic terms, the typhoid fever vaccine in comparison with standard treatment for typhoid fever in four geographic distinct mining work sites. The population included both workers and their households. Using administrative records of healthcare services from an Indonesian HMO, we performed a simulation of the expected economic repercussions of vaccines on direct cost related to disease management (treatment) and indirect cost related to lost days' work (absenteeism). The results show that the standard treatment would cost 5,498,776 rupiah to treat 22 patients, or 249,944 rupiah per patient. Whereas, a vaccination program would cost 2,127,740 rupiah to vaccinate 260 people when the annual risk of contracting the disease is 23 percent and incidence of the disease is 0.0846 . The company's net benefit would be 3,371,036 rupiah The cost-benefit ratio would be 1:1.58; in brief terms, the company would save 1.58 rupiah for every 1 rupiah spent on the program. This study show that typhoid fever vaccine can save cost in the patient's health management of typhoid fever in a working environment. This can suggest that preventive treatment of typhoid fever with typhoid vaccine can provide cost savings in other environments.
\end{abstract}

